SHORT COMMUNICATION

\title{
First record of Vanilla labellopapillata (Orchidaceae: Vanilloideae) in the state of Amazonas, Brazil
}

\author{
Dayse Raiane Passos KRAHL ${ }^{1, *}$, Amauri Herbert KRAHL ${ }^{1}$, Guy $\mathrm{CHIRON}^{2}$, \\ Mário Henrique TERRA-ARAÚJO' \\ 'Instituto Nacional de Pesquisas da Amazônia - INPA, Programa de Pós-Graduação em Botânica, Av. André Araújo 2936, Aleixo, 69060-001 Manaus, AM, Brazil \\ 2Université de Lyon 1, Herbiers, F-69622, Villeurbanne Cedex, France \\ *Corresponding author: dayseraiane@hotmail.com; (D) https://orcid.org/0000-0003-2899-9453
}

\section{ABSTRACT}

The first record of Vanilla labellopapillata is presented for the state of Amazonas, Brazil, in the region of Manaus, now the western limit of the species, which was previously known only from the type locality in the state of Pará. A brief description is provided and taxonomic and ecological aspects of the species are discussed in the light of this new finding.

KEYWORDS: Adolpho Ducke Forest Reserve, Amazon, dense ombrophilous forest, hemiepiphyte, taxonomy

\section{Primero registro de Vanilla labellopapillata (Orchidaceae: Vanilloideae) no Estado do Amazonas, Brasil}

\section{RESUMO}

É apresentado o primeiro registro de Vanilla labellopapillata para o Estado do Amazonas, Brasil, na região de Manaus, sendo este o limite oeste da espécie, anteriormente só conhecida da localidade tipo no estado do Pará. É apresentada uma breve descrição da espécie e comentários taxonômicos e ecológicos da espécie no contexto da nova localidade.

PALAVRAS-CHAVE: Amazônia, floresta ombrófila densa, hemiepífita, taxonomia, Reserva Florestal Adolpho Ducke

Vanilla Plumier ex Miller is a pantropical genus (Cameron 2011; Soto-Arenas and Cribb 2010) and it is composed of just over 100 species (Cameron 2003; Soto-Arenas and Cribb 2010). Its species develop preferentially in tropical forests and a few species are adapted to drier climatic and environmental conditions (Rodolphe et al. 2011). Moreover, the genus has the greatest economic importance among orchids, because Vanilla planifolia Andrews is the natural source of vanilla (Rain 2004).

Species in this genus can be terrestrial, rarely epiphytic and most often hemiepiphytic, some of them being up to $25 \mathrm{~m}$ long (Cameron 2003; Soto-Arenas 2003; SotoArenas and Cribb 2010; Soto-Arenas and Dressler 2010). Curiously, their flowers last less than 12 hours, which very often makes their observation in the wild somewhat difficult (Soto-Arenas 2003; Soto-Arenas and Cribb 2010; SotoArenas and Dressler 2010). The species are characterized by a hemiepiphytic habit, a flexible and lianescent stem, the lack of pseudobulb, alternate leaves with variable sizes and shapes, a lip adnate to the column, a versatile and saddle-shaped anther and entire seeds (Hoehne 1945; Dressler 1993; Soto Arenas and Cribb 2010).
According to Flora do Brasil 2020 in construction (2020), a part of the updated inventory of the Brazilian Flora (BFG 2015), 37 Vanilla species grow in Brazil, 20 being endemic, whereas Soto-Arenas and Dessler (2010) recognized only 26 species in their synopsis of the genus. This discrepancy is due to both new synonyms and the new species described (e.g. Pansarin et al. 2012; Koch et al. 2013; Pansarin and Miranda 2016; Fraga et al. 2017). Again according to BFG 2020 in construction (2020), 17 species have been recorded for the Brazilian Amazon, among which 13 occur in the Amazonas state.

Vanilla labellopapillata A.K. Koch, Fraga, J.U. Santos \& Ilk.-Borg. is one of them. It has been recently described from Pará state, more precisely from the Floresta Nacional de Caxiuanã (Koch et al. 2013). Here we give details on the first record of the species for the state of Amazonas state, which enlarges its geographic distribution. In addition, our finding contributes to the knowledge of the flora of the state of Amazonas. 
Vanilla labellopapillata A.K. Koch, Fraga, J.U. Santos \& Ilk.-Borg., Syst. Bot. 38(4): 975. 2013. (Figure 1A-F).

Hemiepiphytic plant, scandent/lianescent, approximately $15 \mathrm{~m}$ long. Stem cylindric, glabrous, flexible, dark green, internodes $(\mathrm{n}=10) 11.1 \pm 1.8 \times 0.9 \pm 0.09 \mathrm{~cm}$. Leaves $(\mathrm{n}=$ 11) $19.47 \pm 2.75 \times 2.21 \pm 0.28 \mathrm{~cm}$, linear-lanceolate, with an acute and reflexed apex, pseudo-petiole $0.99 \pm 0.09 \mathrm{~cm}$ long. Inflorescence $(\mathrm{n}=6) 12.2 \pm 1.4 \mathrm{~cm}$ long, racemose, 8-13-flowered, originating of the leaf axils. Floral bracts ( $\mathrm{n}$ = 6) $1.02 \pm 0.19 \times 0.65 \pm 0.05 \mathrm{~cm}$, ovate, apically obtuse, smaller towards the raceme apex. Flowers $(n=6)$ pale yellow slightly greenish, pedicellate, pedicel and ovary $5.37 \pm 0.7$ $\mathrm{cm}$ long, cylindric, green near the ovary and white near the pedicel. Sepals oblanceolate, apically obtuse, dorsal $5.60 \pm$ $0.28 \times 1.00 \pm 0.13 \mathrm{~cm}$, lateral $5.33 \pm 0.21 \times 1.13 \pm 0.12 \mathrm{~cm}$; petals $5.40 \pm 0.27 \times 0.80 \pm 0.14 \mathrm{~cm}$, linear-lanceolate, apically obtuse, midvein prominent; lip $3.82 \pm 0.24 \times 2.2 \pm 0.15 \mathrm{~cm}$, clawed, adnate to the column along the margins of the basal half, tubular, ventral surface with rows of imbricated and denticular scales in the middle and anterior portion, papillae becoming enlarged to form a suborbicular tuft of trichomes that covers almost entirely the surface of the median lobe, distinctly trilobed, with a callosity on the disc; penicillated callus $0.35 \pm 0.08 \mathrm{~cm}$ long.; lateral lobes $2.75 \pm 0.12 \times 1.05$ $\pm 0.14 \mathrm{~cm}$, rounded, lateral margins entire, apical margin fimbriate; midlobe $0.63 \pm 0.08 \times 0.70 \pm 0.11 \mathrm{~cm}$, oblong, truncate; column $2.92 \pm 0.13 \mathrm{~cm}$ long, semi-cylindric, slender, sparsely hairy in the ventral region, attenuated at base, with two small membranaceous wings at apex; anthers versatile, saddle-shaped, stigma trilobed; pollen free, yellow. Fruit not seen.

Material examined: Brazil, Amazonas: Manaus, Reserva Florestal Adolpho Ducke, flowered in cultivation in MUSA orchid greenhouse, 19.II.2019, fl., D.R.P. Krahl \& A.H. Krabl 418 (INPA); Idem, fl., D.R.P. Krahl \& A.H. Krabl 419 (INPA); Idem, fl., A.H. Krahl \& D.R.P. Krahl 1093 (INPA); Idem, fl., A.H. Krabl \& D.R.P. Krabl 1094 (INPA); Manaus, BR 174, Km 901, Ramal Castanheira, Sítio Angelim, Dense ombrophilous forest, fl., 24.II.2019, A.H. Krahl \& J.J. Valsko 1109 (INPA); Idem, fl., A.H. Krabl \&J.J. Valsko 1110 (INPA).

Vanilla labellopapillata has been recently described by Koch et al. (2013) from the Pará state. In the present study it was found in two places in a dense ombrophilous forest near the city of Manaus, namely the Reserva Florestal Adolpho Ducke (RFAD), near the area of the botanical garden of the Museu da Amazônia (MUSA) (Museum of Amazonia) and Sítio Angelim, located on the Ramal Castanheira road, Km 901 of the BR 174 highway, that connects Manaus (Amazonas state) to Boa Vista (Roraima state).

According to Koch et al. (2013), V. labellopapillata is a close relative of $V$. insignis Ames. In $V$. insignis, the bracts and the flower parts are larger, the leaf is oblong-elliptic with

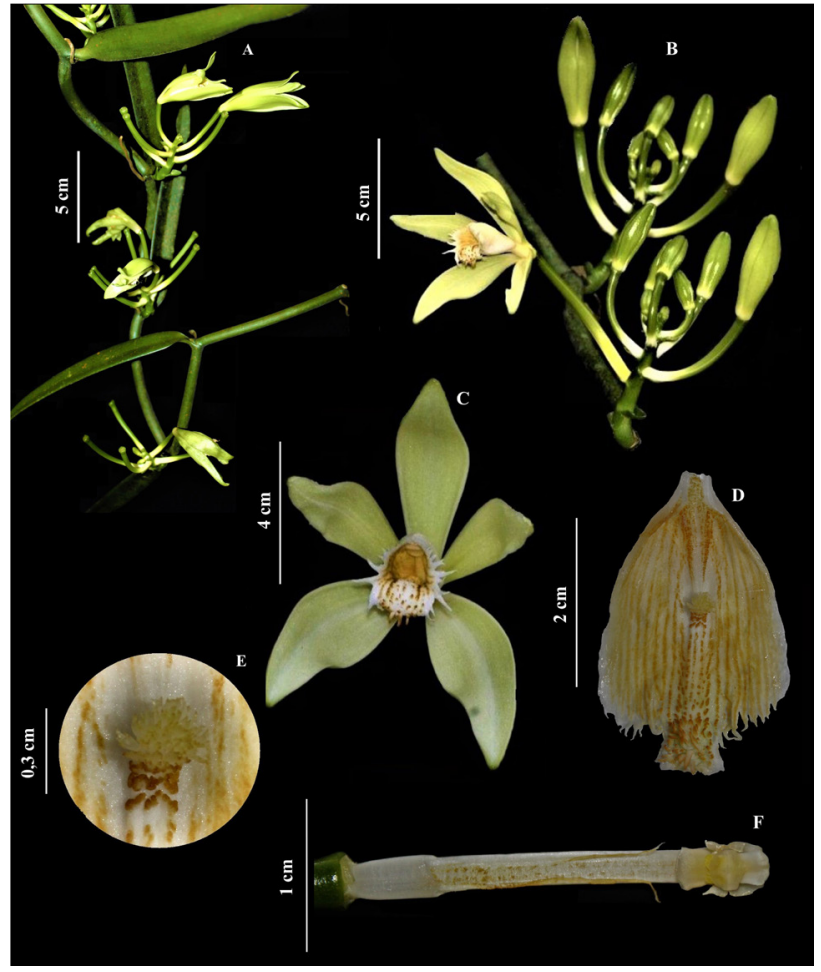

Figure 1. Vanilla labellopapillata. A - Habit; B - Inflorescence; C - Flower; D Lip; E - Callosity of the lip; F - Column in ventral view. This figure is in color in the electronic version.

an abruptly acuminated apex (vs. linear-lanceolate with an reflexed apex) and the penicillate callus is composed of ca. 13 rows of imbricated and congested scales (vs. 3 rows of imbricated and denticular scales) (see more details in Koch et al. 2013). Vanilla insignis was recorded from the Caribbean basin in Central America, in Honduras, Belize, Guatemala and Mexico, at an altitude of ca. $900 \mathrm{~m}$. (Soto-Arenas and Cribb (2010), whereas V. labellopapillata is only found in the Brazilian Amazon, growing in floodplain forest (várzea) (Koch et al. 2013) and terra firme forest (our own observations) at an altitude of about $100 \mathrm{~m}$. This last type of vegetation is therefore a novelty for $V$. labellopapillata, since it had been registered only for várzea forest.

Vanilla labellopapillata can also be confused with $V$. odorata C.Presl [ $=V$. uncinata Huber ex Hoehne according to Garay (1978), Hamer (1984), Dodson and Dodson (1980), SotoArenas and Cribb (2010) and Koch et al. (2013)]. However it differs from $V$. labellopapillata in the longer internodes (approximately over $10 \mathrm{~cm}$ long $v$ s. less than $10 \mathrm{~cm}$ ), shorter floral bracts (less than $6 \mathrm{~mm} v$ s. more than $8 \mathrm{~mm}$ ) and a distinctly trilobed lip without branched and thickened veins and with fimbriate margins ( $v$ s. obscurely trilobed lip with branched and slightly thickened veins in the distal third and long-lacerate/fimbriate to laciniate margins). 


\section{ACKNOWLEDGMENTS}

The authors thank the Programa de Pós-Graduação em Botânica (PPGBot) of Instituto Nacional de Pesquisas da Amazônia (INPA) for support and logistics given throughout the study, Fundação de Amparo à Pesquisa do Estado do Amazonas (FAPEAM) for the scholarship granted to the first author, and the team of the botanical garden of the Museu da Amazônia (MUSA) for their support.

\section{REFERENCES}

BFG 2020 in construction. 2020. Brazilian Flora Group. Vanilla. Jardim Botânico do Rio de Janeiro (http://floradobrasil.jbrj.gov. br/). Accessed on 03 Jun 2020.

BFG. 2015. Brazilian Flora Group. Growing knowledge: an overview of Seed Plant diversity in Brazil. Rodriguésia, 66: 1085-1113.

Cameron, K.M. 2003. Vanilloideae. In: Pridgeon, A.; Cribb, P.; Chase, M.; Rasmussen, F. (Eds.). Genera orchidacearum, v.3. Oxford University, Oxford, p.281-334.

Cameron, K.M. 2011. Vanilla phylogeny and classification. In: Havkin-Frenkel, D.; Belanger, F.C. (Ed.). Handbook of Vanilla Science and technology. WileyBlackwell, Chichester, p.243-255.

Dodson, C.H.; P.M. Dodson. 1980. Orchids of Ecuador. Icones Plantarum Tropicarum v.1-4, Plates 1- 400, Marie Selby Botanical Gardens, Sarasota, 800p.

Dressler, R.L. 1993. Phylogeny and Classification of the Orchid Family. Cambridge University Press, Cambridge, 314p.

Flora do Brasil 2020 em construção. 2020. Orchidaceae. Jardim Botânico do Rio de Janeiro. (http://floradobrasil.jbrj.gov.br/ reflora/floradobrasil/FB12347). Accessed on 03 Jun 2020.

Fraga, C.N.; Couto, D.R.; Pansarin, E.R. 2017. Two new species of Vanilla (Orchidaceae) in the Brazilian Atlantic Forest. Phytotaxa, 296: 63-72.

Garay, L.A. 1978. Orchidaceae (Cypripedioideae, Orchidoideae, Neottioideae). In: Harling, G.W.; Sparre, B.B. (Ed.). Flora of Ecuador, v.9. University of Göteborg and Swedish Museum of Natural History, Goteborg and Stockholm, p.1-305.
Hamer, F. 1984. Orchids of Nicaragua. Icones Plantarum Tropicarum. v.12. (Part. 5), Plates 1101-1200, Marie Selby Botanical Gardens, Sarasota, 400p.

Hoehne, F.C. 1945 Orchidáceas. In: Hoehne, F.C. (Ed.) Flora Brasílica, Fasc. 8 (Vol. XII, II; 13-43). Secretaria da Agricultura, Indústria e Comércio de São Paulo, São Paulo, p.1-389.

Koch, A.K.; Fraga, C.N.; Santos, J.U.M.; Ilkiu-Borges, A.L. 2013. Taxonomic notes on Vanilla (Orchidaceae) in the Brazilian Amazon, and the description of a new species. Systematic Botany, 38: $975-981$

Pansarin, E.R.; Aguiar, J.M.R.B.V.; Ferreira, A.W.C. 2012 A new species of Vanilla (Orchidaceae: Vanilloideae) from São Paulo, Brazil. Brittonia, 64: 157-161.

Pansarin, E.R.; Miranda, M.R. 2016. A new species of Vanilla (Orchidaceae: Vanilloideae) from Brasil. Phytotaxa, 267: 84-88.

Rain, P. 2004. Vanilla: The Cultural History of the World's Favorite Flavor and Fragrance. Jeremy P. Tarcher/Penguin, New York, $371 \mathrm{p}$.

Rodolphe, G.; Séverine, B.; Michel, G.; Pascale, B. 2011. Biodiversity and Evolution in the Vanilla Genus. In: Grillo, O. (Ed.). The Dynamical Processes of Biodiversity —Case Studies of Evolution and Spatial Distribution. O. InTech, Rijeka, p.1-26.

Soto Arenas, M.A.; Cribb, P. 2010. A new infrageneric classification and synopsis of the genus Vanilla Plum. ex Mill. (Orchidaceae: Vanillinae). Lanksteriana, 9: 355-398.

Soto-Arenas, M.A.; Dressler, R.L. 2010. A revision of the Mexican and Central American species of Vanilla Plumier ex Miler with a characterization of their ITS region of the nuclear ribosomal DNA. Lanksteriana, 9: 285-354.

Soto-Arenas, M.A. 2003. Vanilla. In: Pridgeon, A.M.; Cribb, P.J.; Chase, M.W.; Rasmussen, F.N. (Ed.). Genera Orchidacearum: Orchidoideae. Oxford University Press, Oxford, p.321-334.

RECEIVED: 01/05/2020

ACCEPTED: 29/07/2020

ASSOCIATE EDITOR: Ricarda Riina 